\title{
THE ANNA LEONOWENS' ANXIETIES AND EGO DEFENSE MECHANISMS AS FOUND IN ELIZABETH HAND'S ANNA AND THE KING: A FREUDIAN PSYCHOANALYTICAL APPROACH
}

\author{
Gampang Nurtjahyo \\ Faculty of Languages and Arts, PGRI University \\ Semarang, Indonesia \\ gnurtjahyo@yahoo.com
}

\begin{abstract}
All situations which threat individual's comfort can be assumed or considered creating an anxiety. All conflicts, disappointment and feeling of frustration which obstruct individual's progress to reach achievement are also considered as source of anxiety. The threat as it is mentioned can be psychological and physical threats, psychological pressure that all can cause anxiety. There are some ways that can be done by individual to cope with his/her anxiety through some ego defense mechanisms.This reserach is intended to find out Anna Leonowen's anxieties and her ego defense mechanism toward what happens to her during her career as a royal governess in Siam Kingdom. Freudian psycoanalytical approach is chosen in order to explore the main character's personalities.
\end{abstract}

Keywords: anxieties, ego defense, Freudian psychoanalytical approach

\section{INTRODUCTION}

Anna and the King is a novel written by Elizabeth Hand in 1999 based on the screenplay by Steve Meerson and Peter Krikes, Andy Tenant and Rick Parks. This novel was filmed with the same title produced by Twentieth Century Fox Film Corporation. It tells about the adventures of an Englishwoman, Anna Leonowens, who was invited by King Maha Mongkut or His Majesty Phra Chom Klao Rama IV, to teach his children, the King's consorts and concubines inside of Siamese Monarchy in 1862. During Anna Leonowens' duty as the governess in Siamese Monarchy, she had got so many experiences.

The differences in cultures, customs, point of views or perceptions toward certain problems and issues between her and the King gave her anxieties. Oxford Advance Learner's Dictionary, AS Hornby, seventh edition, published by Oxford University Press in 2005 , gives the definition of anxiety as the state of feeling nervous or worried that something bad is going to happen or nervous. Furthermore, there are some points of views from some experts' statements 
toward source of conflicts that cause anxieties which are quoted by David Krech in his book entitled Elements of Psychology as follows:

The source of the conflicts from anxiety is said to arise very widely among different personalities theories: opposing forces among $i d$, ego, and superego (Freud); inferiority feeling versus striving for perfection (Adler); incompatible neurotic needs simultaneously driving the person to seek to be with others, to aggress (Horney); conflicting requirements of complex impersonal relations (Erikson). (Krech, 1974: 578)

All anxieties occured to Anna are repressed by her defense mechanisms she had. These are carried out in order to protect her from having too much tensions or anxieties and to create self-comfort in her. Neil J. Salkin in his book entitled Theories of Human Development and David Krech in his book entitled Elements of Psychology stated as follows:

A defense mechanism is a technique the ego uses to distort reality in the face of dangers that might interrupt healthy psychological development (Salkin, 1985: 94).

Despite this diversity in assumed sources of anxiety, personalities theories seem to agree on the presence of a large number of defense mechanisms that can, to some extent, protect the individual against anxiety, but the price of a certain degree of denial of distortion of reality (Krech, 1974: 578).

In this paper, the writer wanted to explore Anna Leonowens' anxieties and her efforts in repressing her anxieties through defense mechanisms toward Siamese Monarchy during her experiences as a governess for Siamese's royal family in Siamese Kingdom. In conducting his paper, the writer used Freudian psychoanalytical approach as the writer wishes to analyze Anna Leonowens' psychological development as well as her anxieties and defense mechanisms. Psychoanalytical approach was taken in order to help the writer understand the reason of why the main character feels anxious and how she encounters all conflicts she has through defense mechanisms.

In Freudian Psychoanalytic theory, defense mechanisms are unconscious psychological strategies brought into play by various entities to cope with reality and to maintain self-image. Healthy persons normally use different defenses throughout life. An ego defense mechanism becomes pathological only when its persistent use leads to maladaptive behavior such that the physical and/or mental health of the individual is adversely affected. Another definition of defense 
mechanism is taken from Concise Encyclopaedia of Psycology, 1987 which states as follows:

Defense mechanisms are psycological strategy by which persons reduce or avoid negative states such as conflict, frustation, anxiety, and stress. (1987: 295)

From the above concepts of defense mechanism, the purpose of ego defense mechanism is to protect the mind/self/ego from anxiety, social sanctions or to provide a refuge from a situation with which one cannot currently cope. Ego defense mechanism occurs when the id impulses which represent biological instinctual impulses, are in conflict with super-ego values and beliefs, and when an external threat is posed to the ego.

Anna and the King is a novel which contains a lot of psychological conflicts among characters especially as it reveals the main character's anxieties and her ego defense mechanism. That is why the writer assumed that the novel is worth analyzing by using Freudian psychoanalytical approach in order to find out psychological issues or conflicts that exist in Anna Leonowens in it.

\section{DISCUSSION}

Analysis on Anna's Anxieties and Ego Mechanism

All situations which threat individual's comfort can be assumed or considered creating an anxiety. All conflicts, disappointment and feeling of frustration which obstruct individual's progress to reach achievement are also considered as source of anxiety. The threat as it is mentioned can be psychological and physical threats, psychological pressure that all can cause anxiety. In this case, Freud stresses on the importance of anxiety. He differentiates between objective anxiety and neurotic anxiety. Objective anxiety is a realistic response when individual feels insecure in his environment. According to Freud, such condition is the same as a feeling of fear anxiety while neurotic anxiety is a result of conflicts from individual's pre-consciousness that he is not aware of the reason of being anxious (Hilgard et al., 1975:44). Freud, as he believes, think that enxiety is the result of conflicts among id, ego and superego.

1. Anna's repression towards her anxiety on her first arrival 
In the novel entitled Anna and the King, Elizabeth Hand describes how anxious Anna is when she finishes reading a letter from the King Mongkut asking her to teach royal family in Siam Monarcy. Her anxiety is described through her gestures and statement as stated below:

Anna looked up, biting her lip; she quickly folded the letter and replaced it in the envelope. She stood, running her hands across her hair in its neat coif and then resting her palm upon her cheeks. Hot, and there were tears at the corner of her eyes, the only outward signs of her fear (Hand, 1999: 5).

Anna's anxiety is reasonable as her arrival in Siam for fulfilling the King's request for teaching royal family is something that gives her a conflict between her need of money as her husband is no longer with her and her new experience of teaching in the country that she has never been there before. She uses her ego defense mechanism by attempting to repress her anxiety by ignoring her feeling of fear, frustration in order to give her selfcomfort. Her willing to survive after her husband's death and to bring up her child are her motivation to accept the King's invitation no matter how danger working in the place that she has never been before is.

\section{Anna's Repression towards Her being Asked Personal Questions}

Another Anna's anxiety and discomfort occur when she meets the Prime Minister of Siam before she meets the King. The Prime Minister asks her some personal questions concerning with her marriage life. In English custom, it is considered impolite if someone, especially woman, is asked about some personal questions such as age and marital status. The difference custom between English and Siamese gives her anxiety.

Anna felt herself flush. She took a deep breath, forcing her voice to remain level, and said," Could you please convey to His Excellency that my business here is as tutor to the King's eldest son and it is not necessary from him to ask me any more personal questions?" (Hand, 1999: 21)

Once again, she uses her ego defense mechanism by repressing her discomfort of being asked such personal questions. It is because there is a conflict between her $i d$ as an Englishwoman who is expected to be respected, and her super-ego which deals with values and beliefs. Then the external threat which has occurred is posed to the ego. 
3. Anna's Respression towards Her Anxiety on the King's Plan to Reside Her inside the Palace

The King's plan to reside Anna inside the King's palace is the reason of Anna's anxiety and disappointment. Anna thinks that the decision of residing her inside the palace is not in line with the King's promise to provide a home outside the palace for her. Anna tries to convince the Prime Minister but her effort seems to be useless.

"I am sorry, but the King promised us a home of our own outside the palace," said Anna. "It is what was agreed upon Mr. Prime Minister!"

"In Siam you will learn everything has its own time," the Kralahome replied tersely, still ignoring her.(Hand, 1999: 22)

The King's decision makes Anna represses her disappointment and tries to understand the differences between English and Siam customs. She tries to compare the leadership between a queen in her country who never breaks her promise and a king of Siam whom she thinks is inconsistent with what he promises. In this case, there is a conflict between her ego and superego.

"With all due respect," She replied firmly, "in my country, the king is a woman. And she never breaks her promise."

Incensed, the kralahome stood, glaring down at her with contempt.

"Refulting His majesty is not done!"

Anna's heart pounded, but her voice was calm as she inclined her head.

"Then perhaps I, who am not bound by your traditions, should see His Majesty now and remind him of our agreement" (Hand, 1999: 24)

4. Anna's Repression towards Postponing the Meeting with The King

Anna's gesture represents her anxiety and disappointment as described when the meeting with the King is postponed without giving her any reason. It occurs because the concept of time accuracy in Siam, in this case the concept of the word 'soon', is different from English concept. Anna thinks that the word 'soon' means in few days ahead but the fact it has been more than a week.

"Sir, His Excellency regrets that His Majesty, King Mongkut, is unable to meet with you today. But soon. Very soon."

Anna's lips tighthened in a thin smile. She turned to look across the wide boulevard, to where the Kralahome stood upon his terrace, puffing his pipe and strarring down at them. She starred back, feeling blood rise angrily to her cheeks, then looked at the interpreter (Hand, 1999: 39). 
In this case, Anna is trying to repress and hide her anxiety by doing unconscious gesture by tighthening her lips in a thin smile. It is done to minimize her disappointment. This kind of mechanism is aimed to repel desires toward pleasurable instincts, caused by a threat of suffering if the desire is satisfied; the desire is moved to the unconscious in the lapse or lack of awareness of one's own situation and condition; the emotion is conscious but the idea behind is absent.

5. Anna's Reaction Formation towards Slavery in Siam

It is told in the novel that few weeks after Anna starts her teaching, she gets accustomed with Siam Monarchy's customs but one thing that makes her shock when she sees a female slave, La-Ore, who is chained by her master, Lady Jao Jom Manda. The slave is then freed by Anna by giving the slave Anna's ring. The ring, then, is given to her master as the requirement for buying her freedom. Anna's plan to free the slave seems not to be accepted by La-Ore's master. Lady Jao Jom Manda, the slave's owner, reported what anna does to the King and wants her slave to be given back to her. Anna feels disappointed with the way of La-Ore's master in treating her slave. Then, she tries to remind the King's commitment in making Siam Monarchy be part of the modern world.

Anna took a deep breath, then continued. "In your letter confirming my employment, you claimed you wanted Siam to take its place among the nation of modern world. You spoke of 'building something greater' than yourself - a country where no man is above the law." Which is why I chose to come here. (Hand, 1999: 97)

In this case, reaction formation is used by Anna's ego as her defense mechanism. She tries to free the slave owned by the noble family but she herself has Moonshee and Beebe, two of her helpers, as her slaves. This kind of defense mechanism suggests on how individual converts unconscious wishes or impulses that perceived to be dangerous into their opposites; behavior that is completely the opposite of what one really wants or feels; taking the opposite believe because the true belief causes anxiety. This defense can work effectively for coping in the short term, but eventually break down.

6. Anna's Repression towards Preparing King's Anniversary Dinner 
Once King Mongkut says to Anna that he feels uncomfortable of being called "uncivilized" by French diplomats in Siam. Anna then tells him that he is not what they say. The King Mongkut has a plan to hold the King's anniversary dinner in order to create positive image among English nobles and diplomats. The King then orders Anna to prepare the dinner in three weeks with western touch in order to make the invited guests feel at home. The King's order to Anna will be her responsibility in preparing the dinner in three weeks. It gives her anxiety. She feels repressed and thinks that it is impossible to prepare the anniversary in three weeks but the King convinces her that she can do it. She has her own conflict. She realizes that she is employed as governess for royal family. Arranging anniversary dinner is not part of her responsibility but she cannot reject the King's impossible request. It causes anxiety in her.

The King gazed at her. "Thank you, Mem, for humble validation," he said softly. "Then, I, um, have decided to give self anniversary dinner, and invite important English nobles and diplomats."

Anna looked confused. "I don't understand."

"French Indochina grows stronger and more aggressive. But if I improve foreign intercourse with your Queen's envoy, French will think three times before trying to undermine Siam."

"Very clever, Your Majesty," said Anna smiling.

"As if to sound English bugles in own defense." He nodded at her as though something had been decided. "You shall take charge of all formalities, as Mem is obvious choice to make certain guests feel at home."

"And the anniversary is...?"

"Three weeks from yesterday."

"Three weeks! Cried Anna," But that's impossible."(Hand, 1999: 140)

7. Anna's Repression towards Princess Fa-Ying's Death

It is told in the novel that Fa-Ying is the King's favourite daughter. She died for cholera which has spreaded over the Kingdom. This desease has taken the Princess' life. Anna is invited to the palace to see the last minutes of the princess' life. She was shock and sad. She has psichological conflict in her. As a single mother, she can feel the feeling of losing someone she loves. She has experiences of losing her husband. She can feel what the King feels 
and she thinks that the Princess is not supposed to die so young. This moment gives her sadness and anxiety.

In the doorway stood Anna, her heart breaking. She drew a long breath, then walked slowly across the room to where the King sat.

"Fa-Ying", she whispered.

She knelt beside the King, gazing down at the tiny Princess's face. For a moment even the chanting seemed to grow silent, and then Fa-Ying's eyes opened. She stared at Anna, and then recognition smiles stirred her face. Then she turned back to her father, nestling against his breast with a sigh. King Mongkut bent to kiss her forehead, shutting his eyes as the tears began to fall. When he opened them again, the Princess Fa-Ying was still. (Hand, 1999: 184)

\section{Anna's Displacement on Lady Tuptim's Execution}

Lady Tuptim is one of the King's concubines who is brought to the palace as her parents' wish. To be the King's concubine seems not to make her happy since she has a secret lover namely Khun Phra Balat. Soon after she is resided in the palace, she keeps contacting him through the letters that she gives to Anna, her teacher, and given to Balat's courier secretly till the time she decides to run away from the palace and to become a monk. Lady Tuptim's decision is made as she knows that Khun Phra Balat, her lover, becomes a monk. She follows Balat without Balat's knowledge till the King's guards catch both of them. Lady Tuptim is caught and accused of a traitorous act against His Majesty, King Mongkut, which carries of death penalty.

The news of Lady Tuptim's execution makes Anna anxious. She tries to find out the information of the execution from the prime Minister But she does not get a satisfied answer from him till she finally gets information of Lady Tuptim's trial.

In the Hall of Justice, she tries to help Lady Tuptim by defending her and saying that what Lady Tuptim does is for her own happiness. But her defence toward Lady Tuptim is useless.

\section{“Stop!!"}

Heads turned as Anna sprang from her seat, shouting so loudly, her throat ached. "Do you hear me?" Don't you dare lay another hand on her!'

Monshee watched, speechless, as Anna pushed the gallery toward Tuptim, past the sputtering lady jao Jom and other dowagers. But before she could reach Tuptim, the guards grabbed her. Anna struggled with them, turning to shout at Justice Phya Phtom.

"She has done nothing but try to find happiness! 
"Don't touch me!" She kicked savagely at a guard, then went on, panting, "I am going straight to the King! He will put an end to this savagery. (Hand, 1999: 238)

Finally, Anna meets the King. Her meeting with the King seems to make her more and more anxious. It is because the king seems to let lady Tuptim be executed as she has broken law. Anna's intervention seems to make the King angry.

"Forgive me, Your Majesty".

"I do not wish for you to talk more about this, Mem, to King or anyone".

"I am only trying....."

"Tuptim broke law, madam!! Now do as I say, and go!!

Anna stood frozen, staring at him disbelief as he gaze back with stony eyes.

"Why are you behaving like this?" she asked in a low voice. "I know you have matters on tremendous importance weighing on you, but you are a man of honor of compassion."

"She broke law!!" (Hand, 1999: 238)

Time for the Lady Tuptim and Ballat's execution is about to conduct. At Anna's house, she worries about the moment. Her tension is going to arise. Her superego does not seem to accept with what happens to Lady Tuptim and her lover's destiny. They are executed for something they do not commit. It is clearly unproven. There is a conflict in her. As the result, She represses her feeling of her diagreement of the King's decision and displaces her anxiety and disagreement as well as her disappointment by doing destructive things which are not sources of her frustration but safer to attack. It seems that she can not control her ego anymore. She expresses and uses her ego defence mechanism in order to make her more comfortable. It can be seen from the following quotations;

She began to pace mindlessly. A terrible expression crept across her face, as though she was one of the spirit puppets representing a dreadful phi in a shadow play. Back and forth, back and forth. With each step her breathing grew louder and more ragged, her eyes so wide, they seemed to be staring into an abbys. On the hundredth pass across the room she found herself staring at her book self, its titles seeming to waver in the air before her. Vivarium Life.... Oliver Twist...Uncle tom's Cabin (Hand, 1999: 246).

With a strangled cry her hand slashed at them. Books flew everywhere as she ripped them from shelves, tearing the pages out and throwing them around the room in an animal rage. Glass shattered, wood splintered, the last volumetore through the window shutters and landed in the garden outside (Hand, 1999: 246). 


\section{CONCLUSION}

Individual's efforts in reducing the feeling of depression, anxiety, frustation and stress or conflicts are by using ego defense mechanisms both consciously and unconsciously. This is what Sigmund Freud said as quoted from Microsft Encyclopaedia 2002 as follows;

Such defense mechanisms are put into operation whenever anxiety signals a danger that original unacceptable impulses may re-emerge. (Microsoft Encarta Encylopaedia, 2002)

Freud used defense mechanism to describe preconscious processes which protect the individual from his anxiety. Actually these strategies will not change the individual's discomfort condition but change the individual's way to think the conflicts in order to minimize it. So, ego defense mechanism involves the element of self-camouflage.

Anna Leonowens' anxieties and her efforts in reducing her anxieties through defense mechanisms are found in the Elizabeth Hand's novel Anna and the King. Her efforts in reducing her anxieties, as written in the novel, show that she has psychological conflicts during her duties in Siam Monarchy as a governess for royal family there. She uses repression, displacement and reaction formation as her ego defense mechanisms. She uses them for creating selfcomfort and to avoid more conflicts she is likely to have.

\section{REFERENCES}

AS Hornby, Oxford Advance Learner's Dictionary, seventh edition, 2005; Oxford University Press.

Hands, Elizabeth, 1999, Anna and the King,United states of America; Harper Collins Publisher Inc.

Krech, David and S. Crutchfield, Norman Livson, William a. Wilson, Jr., 1974, Elements of Psychology, New York; Third edition; Alfred A. Knopf, inc.

Microsoft Encyclopaedia, 2002. 
Minderop. Albertine, 2010, Psikologi Sastra, Jakarta: Yayasan Pustaka Obor Indonesia.

Salkin., Neil, 1985, Theories of Human Development, Canada; John Wiley \& Sons, Inc. 